\title{
Strategies and Data Analysis Techniques for Lipid and Phospholipid Chemistry Elucidation by Intact Cell MALDI-FTMS
}

\author{
Jeffrey J. Jones, Michael J. Stump, Richard C. Fleming, \\ Jackson O. Lay, Jr. and Charles L. Wilkins \\ Department of Chemistry and Biochemistry, University of Arkansas, Fayetteville, Arkansas, USA
}

\begin{abstract}
Ions attributed to lipids and phospholipids are directly observed by desorption from whole bacteria using intact cell (IC) matrix-assisted laser desorption-ionization (MALDI) Fourier transform mass spectrometry (FTMS). Saccharomyces cerevisiae are grown in rich media broth, concentrated, and applied directly to the MALDI surface without lysis or chemical treatment. FTMS of MALDI ions gives excellent signal to noise ratios with typical resolving powers of 90,000 and mass precision better than $0.002 \mathrm{Da}$. Use of accurate mass measurements and a simple set of rules allow assignment of major peaks into one of twelve expected lipid classes. Subsequently, fractional mass versus whole number mass plots are employed to enhance visual interpretation of the high-resolution data and to facilitate detection of related ions such as those representing homologous series or different degrees of unsaturation. This approach, coupled with rules based on bacterial biochemistry, is used to classify ions with $\mathrm{m} / \mathrm{z}$ up to about 1000. Major spectral peaks in the range $m / z$ 200-1000 are assigned as lipids and phospholipids. In this study, it is assumed that biologically-derived ions with $\mathrm{m} / \mathrm{z}$ values lower than 1000 are lipids. This is not unreasonable in view of the facts that molecular weights of lipids are almost always less than $1000 \mathrm{Da}$, that the copy numbers for lipids in a cell are higher than those for any single protein or other component, and that lipids are generally collections of distinct homologous partners, unlike proteins or other cell components. This paper presents a new rapid lipid-profiling method based on IC MALDI-FTMS. (J Am Soc Mass Spectrom 2004, 15, 1665-1674) (c) 2004 American Society for Mass Spectrometry
\end{abstract}

$\mathrm{M}$ ass spectrometry is increasingly used as a tool in biological analysis [1]. The methods of matrix-assisted laser desorption-ionization (MALDI) [2, 3] and electrospray ionization (ESI) mass spectrometry have contributed significantly to understanding biological systems [4]. Microorganisms are extensively studied by MALDI-TOF mass spectrometry $[2,3,5]$ and, more recently, high resolution MALDIFTMS [6, 7]. With FTMS, resolving powers on the order of 90,000 are typical for ions below $\mathrm{m} / \mathrm{z} 1000$ and allow accurate mass assignments of $10 \mathrm{ppm}$ or better. In other work, intact organisms were examined for lipid content using secondary ion mass spectrometry [8]. A straightforward approach to the analysis of complex mass spectra of phospholipid compounds desorbed directly from whole cell bacteria by MALDI-FTMS is discussed here.

Lipids and phospholipids are among the major components that can be observed in MALDI-Fourier transform mass spectrometry experiments when ions from

Published online September 25, 2004

Address reprint requests to Dr. C. L. Wilkins, Department of Chemistry and Biochemistry, University of Arkansan, Fayetteville, AR 72701, USA. E-mail: cwilkins@uark.edu laser desorption of whole cell bacteria are sampled [6, 9]. Lipids and phospholipids are significant components of all biological cell membranes and are a class of molecules that outnumber proteins and genetic sequence material as cell membrane components [10]. An important factor in mass spectrometry of such compound is that ionization efficiencies for phospholipids depend primarily on the hydrophilic head groups that distinguish each of the lipids. Marto and coworkers [11] investigated MALDI-FTMS of pure phospholipid samples with attention to their fragmentation patterns and MALDI mass spectral identification, emphasizing structural characterization.

Lipids comprise a family of biomolecules that play prominent roles in many critical metabolic and biochemical processes such as energy production and storage, the formation and functioning of cellular membranes, and signal transduction [12]. Lipid analysis, referred to as lipidomics [13], aims at understanding the implications of lipid diversity and how regulation of lipids affects cellular functions. Lipid and phospholipid compositions can change dramatically as a result of environment and cellular activity, with the consequence that phospholipid analysis might be less reliable and inherently more complicated than proteomics for taxo- 
nomic purposes [14]. Use of the common technique of fatty acid methyl ester analysis (FAME) to characterize the lipid fraction of cell membranes is currently implemented with GC/MS as a routine approach to bacterial analysis $[15,16]$. Analysis of pyrolysis products of bacterial whole cells investigated by GC/MS has been proposed as an alternative method to FAME [16,17]. However, both FAME and pyrolysis procedures characterize lipids indirectly by analysis of the chemical derivatives produced during the analytical process [18]. Direct analysis of lipids isolated from organisms has been studied by fast atom bombardment (FAB) mass spectrometry [19-21]. Such measurements provide an adequate analysis, yet are time-consuming.

At present, biological component analysis is heavily focused on proteomic and genomic analysis as the ultimate means of biological characterization [22, 23]. Genomic analysis is a useful but slow means of bacteria identification. Alternatively, proteomic analysis is a potentially faster method of biological characterization and classification. Both methods are widely accepted primarily because of their specificity and utility as tools for comparisons at the species and sub-species level [5, 24-28]. However, to date, only a limited number of analyses have focused on the use of lipid membrane components as a means for complementary bacterial characterization $[9,29,30]$. The methods described here for lipid analysis require limited sample preparation to quickly obtain abundant, accurate mass ion signals from a conventional MALDI-FTMS analysis of whole cell bacteria.

\section{Experimental}

\section{Mass Spectrometry}

MALDI experiments implemented a 9.4 tesla Fourier transform mass spectrometer (IonSpec, Lake Forest, CA). The FTMS instrument contains an external ion source utilizing a quadrupole ion guide to transfer ions to the ICR cell, which is differentially pumped. MALDI employed a Nd-YAG laser operating at $\lambda=355 \mathrm{~nm}$ (New Wave Research, Fremont, CA). The experimental parameters for operation of the FTMS and ion manipulation are described elsewhere [6].

\section{Sample Preparation}

Saccharomyces cerevisiae are grown in tryptic soy broth (TSB) (Sigma, St. Louis, MO.), with a $\mathrm{pH}$ of 7.3 at $35^{\circ} \mathrm{C}$ for $36 \mathrm{~h}$ to ensure high organism density and a fully mature broth culture. Bacteria grown in TSB are combined into $50 \mathrm{~mL}$ centrifuge tubes and centrifuged at about $500 \mathrm{k}$ RCF (relative centrifugation force) for 20 $\mathrm{min}$. The supernatant is poured off and $40 \mathrm{~mL}$ TRIZMA buffer solution (Sigma, St. Louis, MO.) at $35^{\circ} \mathrm{C}$ is added to the sediment, then vortexed to resuspend the bacteria. The cells are again concentrated by centrifugation at about $500 \mathrm{k} \mathrm{RCF}$ for twenty min. The supernatant is poured off and $1.0 \mathrm{~mL}$ of $35^{\circ} \mathrm{C}$ TRIZMA buffer solution is added to the cells to resuspend them. The concentrated cells are transferred to $0.5 \mathrm{~mL}$ vials, vortexed and centrifuged at $25 \mathrm{k} \mathrm{RCF}$ for ten min to concentrate the cells. The supernatant is removed and $0.5 \mathrm{~mL}$ of a solution of 50/50 methanol and milli-conductance deionized water is added. A small portion of this cell suspension (containing $10^{6}$ cells or more) is deposited within $10 \mathrm{~min}$ of workup onto a MALDI surface for analysis [6].

Saccharomyces cerevisiae are additionally grown in mono-express cell growth media (Cambridge Isotope Laboratories, Inc., Andover, MA) depleted of ${ }^{13} \mathrm{C}$ isotope and enriched in ${ }^{15} \mathrm{~N}$ isotope $\left(>99.95 \%{ }^{12} \mathrm{C}\right.$ and $\left.>98 \%{ }^{15} \mathrm{~N}\right)$. Workup conditions for isotopically manipulated organisms are the same as described above [7].

\section{MALDI}

All spectra were obtained using a saturated solution of 2,5-dihydroxybenzoic acid (DHB), dissolved in 90/10 methanol and water. The probe surface is stainless steel, and is cleaned after each analysis. For MALDI experiments, a sandwich sample preparation technique is used. A small amount, $0.5 \mu \mathrm{L}$, of matrix solution is applied to the stainless steel sample surface and evaporated, forming the MALDI matrix surface. Then, $0.7 \mu \mathrm{L}$ of bacterial cell suspension is added and allowed to dry. Last, an additional $0.5 \mu \mathrm{L}$ of matrix solution is applied and allowed to evaporate. In FTMS experiments, $\mathrm{LiCl}$ is used in either 10 or $100 \mathrm{mM}$ aqueous concentrations. Each salt solution is applied, after the deposition of an isotopically depleted bacterial cell suspension, in $0.5 \mu \mathrm{L}$ aliquots and dried before application of final matrix layer.

\section{Data Computations}

Computer programs designed to create and explore a database of possible lipid compositions are written in Microsoft EXCEL and executed using a Pentium 41.6 $\mathrm{GHz}$ computer equipped with $768 \mathrm{MB}$ of RAM memory. Two individual programs are used, one that calculates all of the molecular mass possibilities and another that searches the database of mass tables. Using Christie's Lipid Analysis [31] and Lechevalier's review [10] as guides to the possible lipid compositions found in S. cerevisiae, the masses of ions corresponding to 37 lipid head groups are calculated with carbon chain lengths ranging from 0 to 70 and units of unsaturation ranging from 0 to 5 . Chemical compositions arising from laser-induced fragmentation of phospholipids are considered based on fragmentation schemes proposed after observation of data from purified compounds [32, 33]. Each of these compounds is neutral, therefore the masses corresponding to either $\mathrm{H}^{+}, \mathrm{Li}^{+}, \mathrm{Na}^{+}$, or $\mathrm{K}^{+}$are added to generate a cation species. Particular attention is applied to cation substitution by Li salts because it has been reported that lithium enhances cationization 
[34]. Additionally, lithium has a unique isotopic distribution that allows for an unambiguous interpretation of $\mathrm{Li}^{+}$attachment. The exception is phosphatidyl choline (PC) with a permanent +1 charge. Protonated phosphatidyl ethanolamine (PE) is an isomer of $[\mathrm{PC}]^{+}$, that can be identified by observing prompt fragmentations for both [32, 33]. These calculations resulted in a database look-up-table with 56,232 entries containing possible lipid compositions and corresponding masses. Table 1 is a list of the chemical names, compositions, and abbreviations of the most common lipids and phospholipids expected for organisms such as S. cerevisiae.

\section{Results and Discussion}

\section{Accuracy Requirements}

Knowing the cation species attached to the compound of interest allows assignment with a minimum accuracy of $21.38 \mathrm{ppm}$. The minimum accuracy needed for a compositional assignment to any $\mathrm{m} / \mathrm{z}$ value without knowing the cation species is $0.38 \mathrm{ppm}$. The database look-up-table generated by the computer program is subjected to analysis similar to one described for proteins [35]. As a result of this analysis, the highest number of calculated compositions per one Da increment is found to be 51 at integer mass 1031. These 51 compositions are spread over a 0.607 Da range. According to the analysis, this results in a required accuracy of $11.05 \mathrm{ppm}$ to unambiguously assign a composition to a measured mass. However, the analysis described by Zubarev and coworkers [35] does not consider that compositional masses are not evenly spaced. Mass differences of less than $0.0001 \mathrm{Da}$ occur in $0.87 \%$ of the cases, making an assignment in such a case impossible with today's technology. Table 2 illustrates an example where five possible assignments with varying accuracy are listed for the theoretical $\mathrm{m} / \mathrm{z} 585.355$. It is clear from this example that without knowing the cationizing atom, an accurate assignment is difficult, if not impossible. Mass differences smaller than $0.001 \mathrm{Da}$ occur in $5.76 \%$ of the cases in the database. Half of these result from differences between a hydrogen-cationized spe- cies and another potassium cationized species. The other half are between different hydrogen-cationized compositions. Therefore, if potassium were definitely identified based on the mass spectrum, it would be possible to make these assignments even though accuracy is less than $0.001 \mathrm{Da}$. Mass differences between 0.01 $\mathrm{Da}$ and $0.001 \mathrm{Da}$ occur for $18.62 \%$ of the compositions. Such differences are easily resolved with the resolution and precision achievable by present-day high field FTMS instruments. In the least favorable case, if the cations associated with the masses observed in an FTMS spectrum are definitely identified as lithium (by cation substitution experiments) the minimum accuracy needed for absolute identification is $21.13 \mathrm{ppm}$, which is required in $1.89 \%$ of assignments. Accuracy better than $36.38 \mathrm{ppm}$ is required in $25.27 \%$ of the assignments. It is, therefore, important that high precision and high resolution measurements should be made in conjunction with cation substitution experiments to accurately identify the correct lipid. Additionally, it is assumed that ions in an obvious homologous series (i.e., 2.016 Da and/or 14.016 Da apart) are associated and thus carry the same cationizing ion.

To confirm our observations, and in conjunction with cation substitution experiments, $S$. cerevisiae were grown in media depleted in ${ }^{13} \mathrm{C}$ and enriched in ${ }^{15} \mathrm{~N}$, allowing the determination of the number of nitrogen atoms in any ion. Wherever the predicted assignment included one nitrogen atom, the observed mass shifted $+1 \mathrm{Da}$. In all cases where the predicted assignment did not include nitrogen atoms, the observed mass did not shift.

\section{S. cerevisiae Mass Spectra}

Mass spectra acquired for S. cerevisiae included numerous peaks with average resolving power greater than 90,000 and a calculated average precision of $0.0020 \mathrm{Da}$. Figure 1 is a typical mass spectrum of $S$. cerevisiae. The structure drawn for the observed $\mathrm{m} / \mathrm{z} 184.074$ is the polar head group for phosphatidyl choline, strongly indicating the presence of this lipid class. It should be noted that to obtain the highest resolution in FTMS,

Table 1. Lipids used in mass assignment calculations for S. cerevisiae

\begin{tabular}{llc}
\hline \multicolumn{1}{c}{ Chemical name } & Short name & Chemical composition \\
\hline \hline Phosphatidic acid or phospholipid fragment & $\mathrm{PA} /(\mathrm{PL})$ & $\left.\mathrm{C}_{5} \mathrm{H}_{7} \mathrm{O}_{8} \mathrm{P}-([\mathrm{R}]-\mathrm{CH})_{3}\right)_{2}$ \\
Phosphatidyl ethanolamine & $\mathrm{PE}$ & $\mathrm{C}_{7} \mathrm{H}_{12} \mathrm{O}_{8} \mathrm{NP}^{-}([\mathrm{R}]-\mathrm{CH})_{2}$ \\
Phosphatidyl choline & $\mathrm{PC}$ & $\mathrm{C}_{10} \mathrm{H}_{19} \mathrm{O}_{8} \mathrm{NP}^{-}\left([\mathrm{R}]-\mathrm{CH}_{3}\right)_{2}$ \\
Phosphatidyl glycerol & $\mathrm{PG}$ & $\mathrm{C}_{8} \mathrm{H}_{13} \mathrm{O}_{10} \mathrm{P}-\left([\mathrm{R}]-\mathrm{CH}_{3}\right)_{2}$ \\
Diphosphatidyl glycerol (cardiolipin) & $\mathrm{DPG}$ & $\mathrm{C}_{13} \mathrm{H}_{8} \mathrm{O}_{17} \mathrm{P}_{2}-\left([\mathrm{R}]-\mathrm{CH}_{3}\right)_{4}$ \\
Phosphatidyl inositol & $\mathrm{PI}$ & $\mathrm{C}_{11} \mathrm{H}_{17} \mathrm{O}_{13} \mathrm{P}-\left([\mathrm{R}]-\mathrm{CH}_{3}\right)_{2}$ \\
Phosphatidyl serine & $\mathrm{PS}$ & $\mathrm{C}_{8} \mathrm{H}_{12} \mathrm{O}_{10} \mathrm{NP}_{-}\left([\mathrm{R}]-\mathrm{CH}_{3}\right)_{2}$ \\
Triglyceride -or - triacyl-glycerol & $\mathrm{TAG}$ & $\mathrm{C}_{6} \mathrm{H}_{5} \mathrm{O}_{6}-\left([\mathrm{R}]-\mathrm{CH}_{3}\right)_{3}$ \\
Diacyl glycerol & $\mathrm{DAG}$ & $\mathrm{C}_{5} \mathrm{H}_{6} \mathrm{O}_{5}-\left([\mathrm{R}]-\mathrm{CH}_{3}\right)_{2}$ \\
Monoacyl glycerol & $\mathrm{MAG}$ & $\mathrm{C}_{4} \mathrm{H}_{7} \mathrm{O}_{4}-[\mathrm{R}]-\mathrm{CH}_{3}$ \\
Phospholipid - head group & $\mathrm{PL}-\mathrm{HG}$ & $\mathrm{C}_{5} \mathrm{H}_{5} \mathrm{O}_{4}-\left([\mathrm{R}]-\mathrm{CH}_{3}\right)_{2}$ \\
Fatty acid & $\mathrm{FA}$ & $\mathrm{HCO}_{2}-[\mathrm{R}]-\mathrm{CH}_{3}$ \\
\hline
\end{tabular}


Table 2. Assignments for the measured $m / z 585.355$ with varying accuracy. By knowing the cationizing atom, assignment to [TAG $30: 4+\mathrm{K}]^{+}$is possible, even if the accuracy was $50 \mathrm{ppm}$.

\begin{tabular}{|c|c|c|c|c|}
\hline Exact mass & Lipid short name & Chemical composition & Mass deviation & ppm Error \\
\hline 585.2959 & 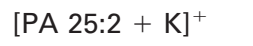 & $\mathrm{C}_{28} \mathrm{H}_{51} \mathrm{O}_{8} \mathrm{PK}$ & 0.0591 & 100.96 \\
\hline 585.3532 & {$[\mathrm{PA} 26: 1+\mathrm{Na}]^{+}$} & $\mathrm{C}_{29} \mathrm{H}_{55} \mathrm{O}_{8} \mathrm{PNa}$ & 0.0018 & 3.08 \\
\hline 585.3556 & {$[\mathrm{PA} \mathrm{28:4}+\mathrm{H}]^{+}$} & $\mathrm{C}_{31} \mathrm{H}_{54} \mathrm{O}_{8} \mathrm{P}$ & -0.0006 & -1.03 \\
\hline 585.3557 & {$\left[\right.$ TAG 30:4 + K] ${ }^{+}$} & $\mathrm{C}_{33} \mathrm{H}_{54} \mathrm{O}_{6} \mathrm{~K}$ & -0.0007 & -1.20 \\
\hline 585.3921 & [DAG $31: 4$ + K]+ & $\mathrm{C}_{34} \mathrm{H}_{58} \mathrm{O}_{5} \mathrm{~K}$ & -0.0371 & -63.38 \\
\hline
\end{tabular}

Experimentally Measured Mass $=585.355 \mathrm{~m} / \mathrm{z}$

detection times must be maximized. For longer detection times, ions of low abundance are not detected for the full duration of acquisition and are averaged out by the fast Fourier transform (FFT). However, low abundance ions can be observed by transforming fewer data points, at the cost of lower resolution. For example, ions with $\mathrm{m} / \mathrm{z} 800$ or higher are only evident in an FFT for $512 \mathrm{~K}$ data of a $2048 \mathrm{~K}$ data acquisition. Use of this strategy is important because it allows measurement of less abundant ion masses so as to best characterize an organism's lipid and phospholipid profile. Careful external calibrations using poly(ethylene glycol) 600 resulted in mass assignments to ions of significant abundance with an average of $4.3 \mathrm{ppm}$ error. Ions collected for analysis in the FTMS cell are subjected to broadband ion isolation between $\mathrm{m} / \mathrm{z} 200$ and 1200 to ensure minimal space-charge effects by unobserved ions [36]. Only monoisotopic masses are considered for assignments. However, in the case of natural abundance media, it is difficult to resolve the mass difference arising from addition of two hydrogens to an unsaturated bond $(2.016 \mathrm{Da})$ from that associated with the presence of two ${ }^{13} \mathrm{C}$ isotopes in an ion with one lower degree of saturation $(2.007 \mathrm{Da})$. One way to assess the relative contributions is to compare the $\mathrm{A}+2$ ion abundance with that expected by theory for the A +2 ${ }^{13} \mathrm{C}$ for the relevant composition. If the abundance is significantly greater than theory, then hydrogen addition can be considered a contributor to the ion structure being detected. Identification of lipids and phospholipids in an FTMS mass spectrum is further validated by data interpretation techniques using mass defect plots. Such plots are designed as a rapid visual tool for analyzing spectra from whole cell bacteria. Mass defect plots developed in the present study are similar to Kendrick mass plots [37, 38] and Van Krevelen diagrams $[39,40]$ except that mass tables are not converted to nitrogen-based 14.000, rather than the measured normal carbon-based 12.000. Instead, the raw measured accurate masses are separated into integer and decimal (fractional mass) parts. Those data are then plotted as fractional mass versus integer mass, resulting in a plot in which each observed mass corresponds to a single two dimensional Cartesian coordinate. Such mass de-

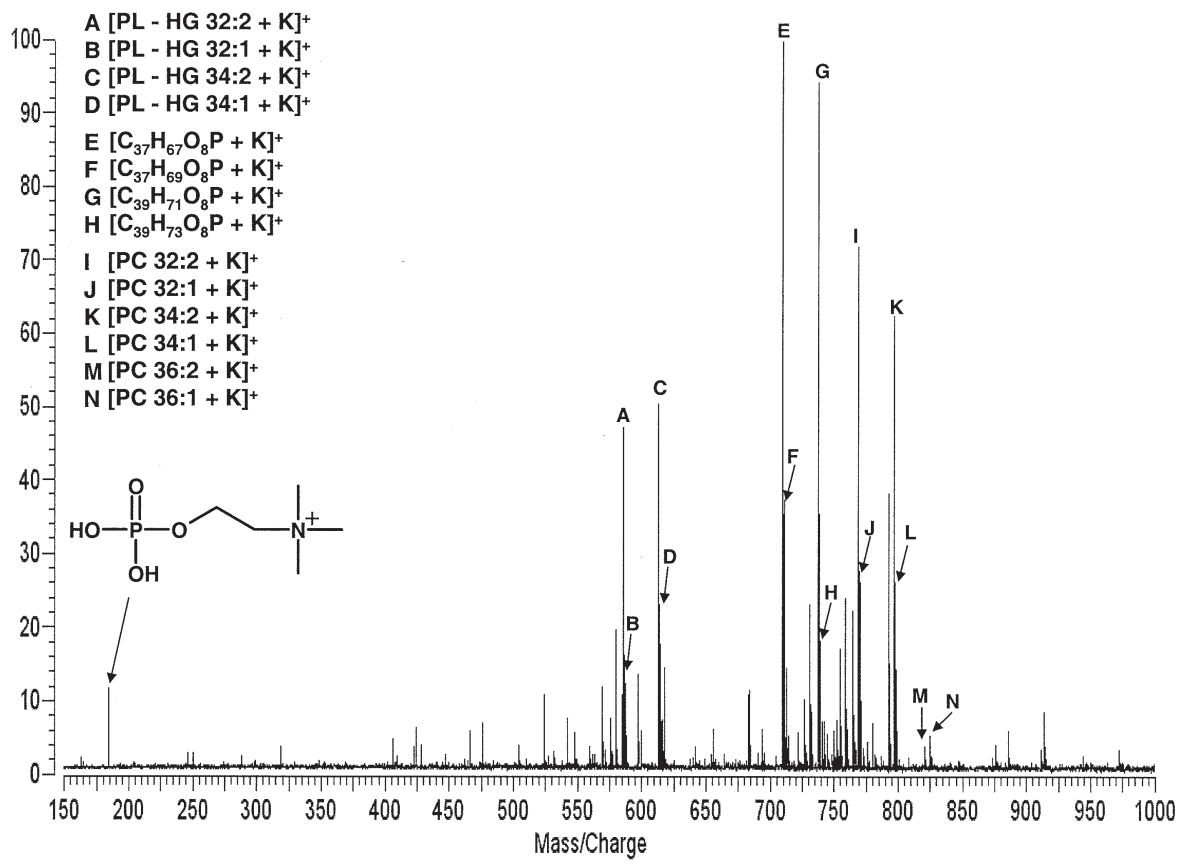

Figure 1. FTMS of S. cerevisiae grown in natural isotopic abundance media. The structure for the observed $\mathrm{m} / \mathrm{z} 184.07$ is the polar head group for PC, strongly indicating the presence of this lipid class. 
fect plots are useful because elemental compositions for calculated exact monoisotopic masses can give rise to specific fractional masses unique to a given elemental composition. For example, for every nitrogen atom (monoisotopic mass: $14.00307 \mathrm{Da}$ ) in a molecule, the fractional mass increases by $0.00307 \mathrm{Da}$. Similarly, for every oxygen atom (monoisotopic mass: $15.99492 \mathrm{Da}$ ) in a molecule, the fractional mass decreases by $0.00508 \mathrm{Da}$. In the case of lipids and phospholipids, each polar head group has a specific elemental composition determining the base fractional mass. Carbon chain length $\left(\mathrm{CH}_{2}\right.$, $14.016 \mathrm{Da})$ and unsaturation $\left(\mathrm{H}_{2}, 2.016 \mathrm{Da}\right)$ are the only variables in the elemental composition that change the fractional mass within a lipid species. Figure 2 shows the calculated exact lowest isotopic masses for phosphatidic acid (PA), phosphatidyl inositol (PI), phosphatidyl serine (PS), phosphatidyl ethanolamine (PE), phosphatidyl choline (PC), phosphatidyl glycerol (PG), diphosphatidyl glycerol (cardiolipin) (DPG), triacylglycerides (TAG), diacyl-glycerides (DAG), and monoacyl-glycerides (MAG) when viewed in a mass defect plot. In this plot ${ }^{6} \mathrm{Li}$ is used, rather than the more abundant ${ }^{7} \mathrm{Li}$ isotope. Assignments restricted to these ten are based on their occurrence in microorganisms [41] and their percentages of the total fatty acid composition as determined by Lechevalier [10].

Mass defect plots are utilized here to highlight impossible mass defects for the compounds considered, and suggest chemical compositions for unknown or unpredicted ions. Ions corresponding to phospholipid fragments missing the polar head group $\left[\mathrm{C}_{3} \mathrm{H}_{5} \mathrm{O}_{4}\left(\mathrm{CH}_{2}\right)_{\mathrm{n}}\left(\mathrm{CH}_{3}\right)_{2}-\mathrm{PO}_{4} \mathrm{H}_{2}\left(\mathrm{CH}_{2}\right)_{2} \mathrm{~N}\left(\mathrm{CH}_{3}\right)_{3}\right]$ were at first classified as unknown, until the fractional mass of each was revealed to contain four oxygen atoms inclusive of carbon and hydrogen hydrophobic chains. Knowing what atoms contribute to the mass defect for each unknown ion aided in the realization that these ions are possibly fragments originating from phospholipids whose observed $\mathrm{m} / \mathrm{z}$ values have been identified in literature from isolated phospholipids [32,33]. Above the line labeled Lipid Fractional Mass Boundary, the fractional mass of any peak is inconsistent with expected values for lipid species and is unknown; these peaks may arise either from the presence of unknown chemical constituents or electronic noise. Some metabolites rich in oxygen content do have small mass defects. These can be distinguished from common electronic noise peaks by peak width, which is too narrow to be considered an ion. Below the line bounding the lower limit of the calculations, the fractional mass of any peak plotted is too small to be consistent with assignment as a lipid or phospholipid. Peptides and protein fragments can be calculated and plotted according to their nominal and fractional masses, similar to lipids and phospholipids. Possible peptide masses are described in a similar manner and follow similar analysis [35]. Misidentification of a mass as a lipid and not a peptide is also unlikely because lipids follow distinct patterns of homologous series (i.e., unsaturation and carbon chain length) similar to a polymer series, whereas peptides generally do not. The elemental composition that governs the chemical makeup of proteins is richer in oxygen than lipids and therefore, when plotted in the same manner as the lipids and phospho-

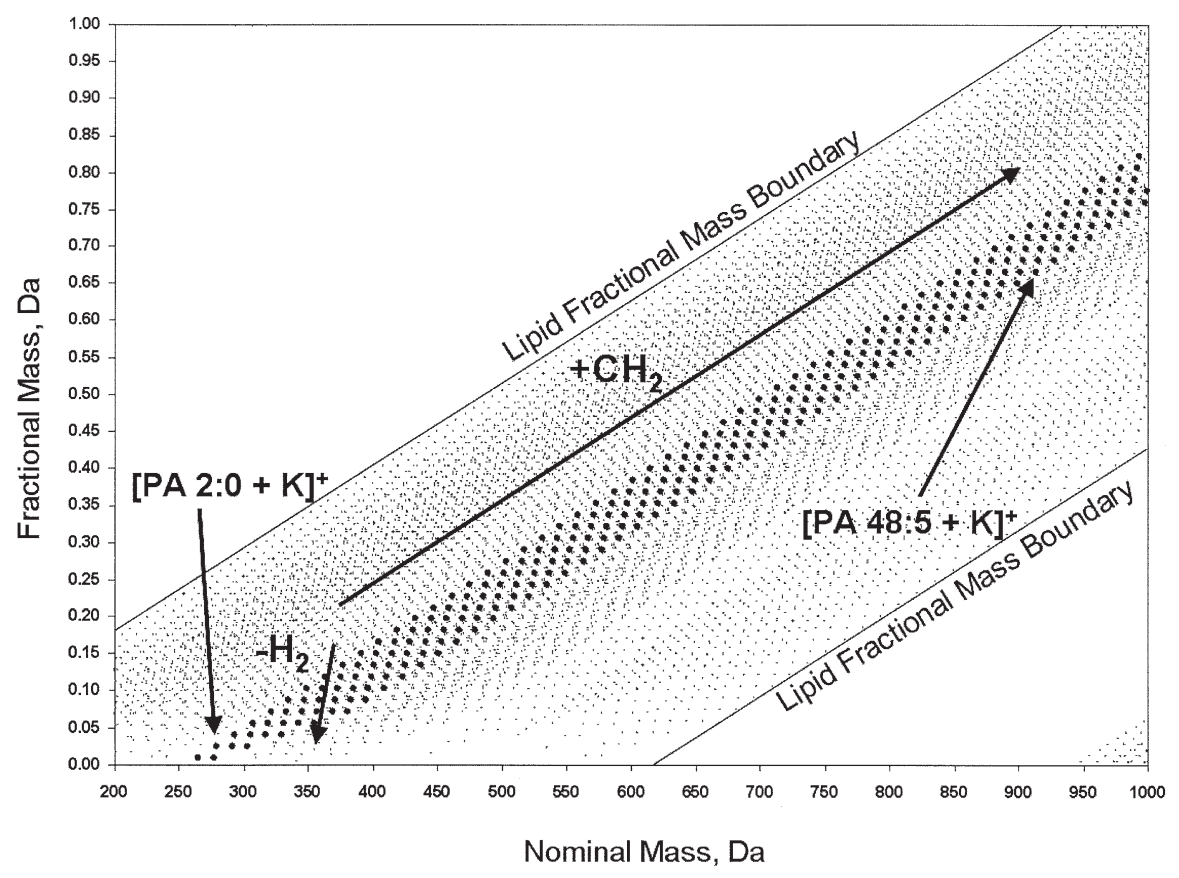

Figure 2. Mass defect plot. In the background, masses for each of 19,008 compositions are plotted, fractional mass versus integer mass. In the foreground, masses for only $[\mathrm{PA}+\mathrm{K}]^{+}$are plotted for visual display of the $+\mathrm{CH}_{2}$ and $-\mathrm{H}_{2}$ slopes. 
lipids, results in a separate region that is readily visualized on a mass defect plot, overlapping lipid compositions only in the low fractional mass region, typically below 0.3 . The majority of the peaks in the low mass region of mass spectra of $S$. cerevisiae have fractional masses that fall within the limits of the calculations for lipids and plot accordingly in the mass defect plot of Figure 3. This representation enhances obvious homologous series not evident in a conventional mass spectral display. Outlined are groupings of lipids and phospholipids as assigned from data analysis and mass searching the table of lipid compositions and masses. Distinct clusterings of fragments are easily visualized; so are species of cationized phosphatidyl choline lipids. Grouping of ions into distinct regions is expected for mass defect plots for each of the lipid head groups, and contributing cation is shared for each grouping; a feature not evident in conventional mass spectral display. For organism specificity with respect to MALDIFTMS, it should be noted that previous work has demonstrated bacterial species differentiation [9, 42].

Monoisotopic enhancement, by ${ }^{13} \mathrm{C}$ depletion and ${ }^{15} \mathrm{~N}$ enrichment reveals unsaturation and carbon chain length without confusion from normal isotopic contributions. This also facilitates cation elucidation in cation competition studies (Figure 4). Resolving power and signal to noise ratio are improved by eliminating isotopic contributions from carbon through the use of ${ }^{13} \mathrm{C}$ depleted media, allowing longer signal transients to be collected and reducing space charge influences [36]. Mass accuracy is improved along with mass precision.
Table 3 is a list of masses and assignments to masses that appear in at least 12 of 16 spectra derived from 2048 $\mathrm{K}$ data point acquisitions, taken at $2 \mathrm{MHz}$ ADC acquisition rate. The accurate assignments in Table 3 are based on reproducibility of abundance and mass accuracy compared to calculated exact masses. All reported masses represent the same $\mathrm{m} / \mathrm{z}$ ions with an average \pm 0.0020 Da precision over 25 spectra collected at $2048 \mathrm{~K}$ data, which is then processed by FFT at $2048 \mathrm{~K}, 1024 \mathrm{~K}$, and $512 \mathrm{~K}$. This is annotated in Table 3. It is important to include less abundant ion masses to best characterize an organism's lipid and phospholipid profile. For example, the ion with $m / z 824.559$ is important in characterizing the fragment ions of $m / z 765.486$, one of the more prominent ions in the spectrum. Even when accuracy, resolution, and confidence are sacrificed by reducing the number of data points used in an FFT, there is still valuable information that may be considered in the characterization of the lipid profile, as illustrated in Table 4. By searching a spectrum for exact mass differences for both the trimethylamine loss $\left[-\mathrm{N}\left(\mathrm{CH}_{3}\right)_{3}, 59.074 \mathrm{Da}\right]$ and the phospholipid head group loss $\left[-\mathrm{PO}_{4} \mathrm{H}_{2}\left(\mathrm{CH}_{2}\right)_{2} \mathrm{~N}\left(\mathrm{CH}_{3}\right)_{3}, 184.074 \mathrm{Da}\right]$ the presence of PC can be determined. Similarly, the exact mass difference for the phospholipid head group loss of $\mathrm{PE}\left[-\mathrm{PO}_{4} \mathrm{H}_{2}\left(\mathrm{CH}_{2}\right)_{2} \mathrm{NH}_{2}, 141.019 \mathrm{Da}\right]$ is indicative of PE. Fragmentation from the parent ions can be used to distinguish the isomers PC and PE. In these experiments, the exact mass difference of 141.019 Da was not observed, ruling out PE as a possible assignment for an isomeric pair. The presence of both exact mass differ-

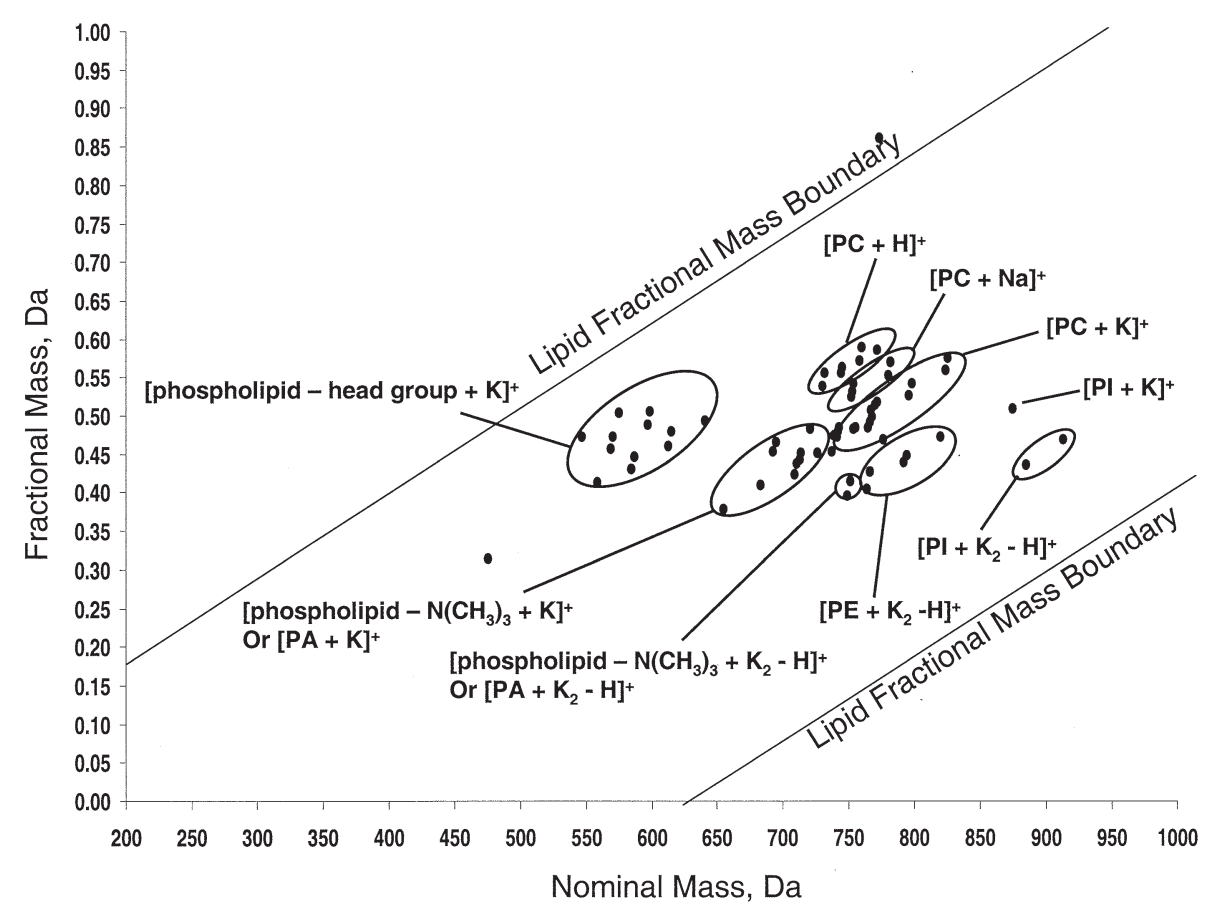

Figure 3. Mass defect for S. cerevisiae cultured in natural isotopic abundance media. Clustering of ions into distinct regions is expected for mass defect plots. Individual lipid head groups with associated cation cluster: a feature not evident in a conventional mass spectral display. 


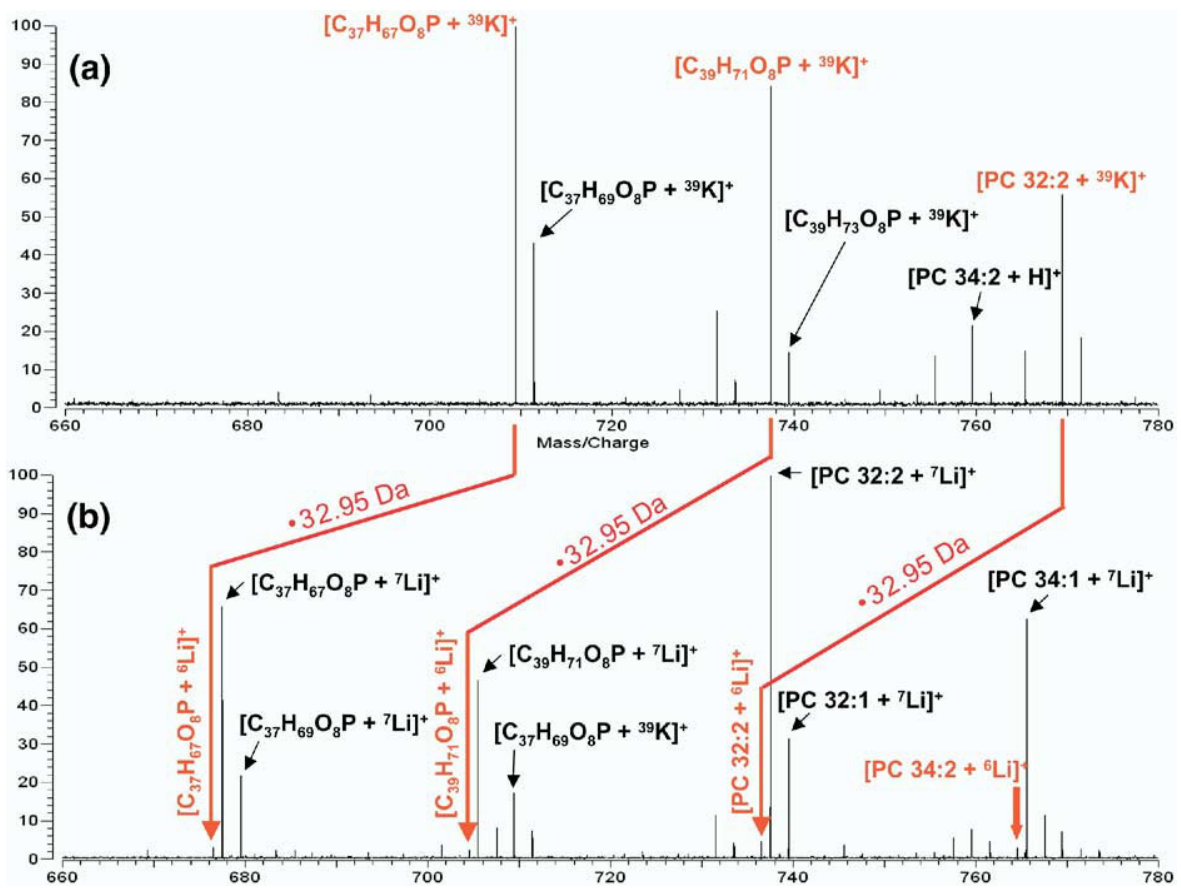

Figure 4. High resolution portion of two S. cerevisiae MALDI Fourier transform mass spectra. Spectrum (a) is the original mass spectrum with no salts intentionally added to the MALDI sample. Spectrum (b) results when $\mathrm{LiCl}$ is added to the MALDI sample. Chemical compositions are supplied for labels where assignments have possible isomers.

ences of 59.074 Da and 184.074 Da confirms the assignment of PC. However as shown in Table 4, a majority of the fragment peaks have isomers that cannot be distinguished. It should be noted that trimethylamine loss from PC and PA have the same chemical compositions.

MALDI spectra obtained when specific cations are added can reveal occurrence of competition between the added cation and adventitious cations. For example, when lithium chloride is added to isotopically depleted $\left({ }^{13} \mathrm{C}\right.$ and $\left.{ }^{15} \mathrm{~N}\right)$ samples of $S$. cerevisiae, the lithium peaks can be identified unambiguously by the presence of their isotopic patterns. Added $\mathrm{Li}^{+}$cations shift peak masses, as evident in Figure 4, from those observed during MALDI spectral acquisition in the absence of such additions. Figure $4 \mathrm{~b}$ shows the results of the Li salt addition to an isotopically-depleted Saccharomyces cerevisiae sample with each $\mathrm{Li}^{+}$identified peak having a mass shift matched to that of the spectrum in the absence of Li. It is evident that potassium-cationized ions dominate the original mass spectrum, likely a result of the buffer used in microorganism preparation. When $\mathrm{KCl}$ is added, the spectra do not change. Addition of $\mathrm{Li}^{+}$allows choices between alternative sodium or potassium cationization assignments [43].

\section{Conclusions}

The method for lipid analysis by MALDI-FTMS described here can be applied directly to in-vivo characterization of lipid compounds. Use of MALDImeasured accurate mass values combined with mass defect plots is rapid, accurate, and simpler then conventional liquid chromatographic methods [12]. Intact cell MALDI-FTMS bacterial lipid characterization complements the use of proteomics profiling by mass spectrometry because it relies on accurate mass measurements of lipid species that are not subject to post-translational modification or proteolytic degradation.

The present results further establish the utility of MALDI-FTMS for mass spectral analysis of whole cell bacteria and complex single-celled organisms. Use of FTMS provides the needed mass accuracy. Measured accurate masses from MALDI-FTMS of whole cell bacteria, therefore, can be used to identify hydrocarbon chain lengths and lipid compounds present. Reproducibility between spectra is excellent and when the present growth conditions are used, spectra of samples grown and analyzed a year apart are qualitatively identical. Identification of constituents of cells, combined with bacterial classification schemes based on MALDI-identified proteins, may lead to a rapid screening method for microorganism identification. Furthermore, this method could directly replace the FAME test and pyrolysis methods

\section{Acknowledgments}

The authors gratefully acknowledge support under National Science Foundation grants CHE-00-79240, CHE-00-91868, and CHE99-82045. The authors also thank Jerry Holmsley and Jacob Kaufman for valuable technical assistance. 
Table 3. Mass assignments for peaks in the FTMS spectrum of $S$. cerevisiae incubated in natural abundance growth media. Spectra acquired at $2048 \mathrm{~Kb}$ data for a $2 \mathrm{MHz}$ ADC scan.

\begin{tabular}{|c|c|c|c|c|c|c|}
\hline $\begin{array}{c}\text { Measured accurate } \\
m / z(\mathrm{Da})\end{array}$ & $\begin{array}{c}\text { Data points } \\
\text { used in FFT } \\
(\mathrm{Kb})\end{array}$ & $\begin{array}{c}\text { Measured } \\
\text { precision }(\mathrm{Da})\end{array}$ & $\begin{array}{c}\text { Calculated exact mass } \\
\text { assignment }\end{array}$ & $\begin{array}{c}\text { Calculated } \\
\text { exact } \\
\text { mass (Da) }\end{array}$ & $\begin{array}{c}\text { Mass } \\
\text { accuracy } \\
(\mathrm{Da})\end{array}$ & $\begin{array}{l}\text { ppm } \\
\text { Error }\end{array}$ \\
\hline 547.4729 & 512 & 0.0010 & {$[\mathrm{PL}-\mathrm{HG} 32: 2+\mathrm{H}]^{+}$} & 547.4726 & 0.0003 & 0.5 \\
\hline 559.4132 & 512 & 0.0010 & {$[\mathrm{PL}-\mathrm{HG} 30: 1+\mathrm{K}]^{+}$} & 559.4129 & 0.0003 & 0.5 \\
\hline 569.4556 & 2048 & 0.0011 & {$[\mathrm{PL}-\mathrm{HG} 32: 2+\mathrm{Na}]^{+}$} & 569.4546 & 0.0010 & 1.8 \\
\hline 571.4716 & 2048 & 0.0019 & {$[\mathrm{PL}-\mathrm{HG} 32: 1+\mathrm{Na}]^{+}$} & 571.4702 & 0.0014 & 2.4 \\
\hline 585.4299 & 2048 & 0.0017 & {$[\mathrm{PL}-\mathrm{HG} 32: 2+\mathrm{K}]^{+}$} & 585.4285 & 0.0014 & 2.4 \\
\hline 587.4459 & 2048 & 0.0010 & {$[\mathrm{PL}-\mathrm{HG} 32: 1+\mathrm{K}]^{+}$} & 587.4442 & 0.0017 & 2.9 \\
\hline 597.4872 & 2048 & 0.0010 & {$[\mathrm{PL}-\mathrm{HG} 34: 2+\mathrm{Na}]^{+}$} & 597.4859 & 0.0013 & 2.2 \\
\hline 599.5057 & 2048 & 0.0016 & {$[\mathrm{PL}-\mathrm{HG} 34: 1+\mathrm{Na}]^{+}$} & 599.5015 & 0.0042 & 7.0 \\
\hline 613.4599 & 2048 & 0.0021 & {$[\mathrm{PL}-\mathrm{HG} 34: 2+\mathrm{K}]^{+}$} & 613.4598 & 0.0001 & 0.2 \\
\hline 615.4799 & 2048 & 0.0008 & {$[\mathrm{PL}-\mathrm{HG} 34: 1+\mathrm{K}]^{+}$} & 615.4755 & 0.0044 & 7.1 \\
\hline 641.4934 & 512 & 0.0012 & {$[\mathrm{PL}-\mathrm{HG} 36: 2+\mathrm{K}]^{+}$} & 641.4911 & 0.0023 & 3.6 \\
\hline 655.3774 & 2048 & 0.0016 & $(\mathrm{PL}) \mathrm{C}_{33} \mathrm{H}_{61} \mathrm{O}_{8} \mathrm{PK}^{+}$ & 655.3741 & 0.0033 & 5.0 \\
\hline 683.4094 & 2048 & 0.0016 & (PL) $\mathrm{C}_{35} \mathrm{H}_{65} \mathrm{O}_{8} \mathrm{PK}^{+}$ & 683.4054 & 0.0040 & 5 \\
\hline 693.4522 & 1024 & 0.0015 & $(\mathrm{PL}) \mathrm{C}_{37} \mathrm{H}_{67} \mathrm{O}_{8} \mathrm{PNa}^{+}$ & 693.4471 & 0.0051 & 7 \\
\hline 695.4655 & 1024 & 0.0023 & (PL) $\mathrm{C}_{37} \mathrm{H}_{69} \mathrm{O}_{8} \mathrm{PNa}^{+}$ & 695.4628 & 0.0027 & 3.9 \\
\hline 709.4233 & 2048 & 0.0015 & $(\mathrm{PL}) \mathrm{C}_{37} \mathrm{H}_{67} \mathrm{O}_{8} \mathrm{PK}^{+}$ & 709.4211 & 0.0022 & 3.1 \\
\hline 711.4380 & 2048 & 0.0012 & (PL) $\mathrm{C}_{37} \mathrm{H}_{69} \mathrm{O}_{8} \mathrm{PK}^{+}$ & 711.4367 & 0.0013 & 1.8 \\
\hline 713.4421 & 2048 & 0.0011 & (PL) $\mathrm{C}_{37} \mathrm{H}_{71} \mathrm{O}_{8} \mathrm{PK}^{+}$ & 713.4524 & -0.0103 & -14.4 \\
\hline 714.4506 & 2048 & 0.0025 & {$[\mathrm{PC} 28: 1+\mathrm{K}]^{+}$} & 714.4476 & 0.0030 & 4.2 \\
\hline 721.4826 & 512 & 0.0032 & (PL) $\mathrm{C}_{39} \mathrm{H}_{71} \mathrm{O}_{8} \mathrm{PNa}^{+}$ & 721.4784 & 0.0042 & 5.8 \\
\hline 726.4514 & 2048 & 0.0027 & {$[\mathrm{PE} 32: 2+\mathrm{K}]^{+}$} & 726.4476 & 0.0038 & 5.2 \\
\hline 730.5386 & 2048 & 0.0032 & {$[\mathrm{PC} 32: 2+\mathrm{H}]^{+}$} & 730.5387 & -0.0001 & -0.1 \\
\hline 732.5566 & 1024 & 0.0011 & {$[\mathrm{PC} 32: 1+\mathrm{H}]^{+}$} & 732.5543 & 0.0023 & 3.1 \\
\hline 737.4524 & 2048 & 0.0021 & (PL) $\mathrm{C}_{39} \mathrm{H}_{71} \mathrm{O}_{8} \mathrm{PK}^{+}$ & 737.4530 & -0.0006 & -0.8 \\
\hline 739.4734 & 2048 & 0.0011 & (PL) $\mathrm{C}_{39} \mathrm{H}_{73} \mathrm{O}_{8} \mathrm{PK}^{+}$ & 739.4680 & 0.0054 & 7.3 \\
\hline 742.4798 & 2048 & 0.0021 & {$[\mathrm{PC} 30: 1+\mathrm{K}]^{+}$} & 742.4789 & 0.0009 & 1.2 \\
\hline 744.5565 & 2048 & 0.0025 & {$[\mathrm{PE} 36: 2+\mathrm{H}]^{+}$} & 744.5543 & 0.0022 & 3.0 \\
\hline 749.3946 & 512 & 0.0033 & (PL) $\mathrm{C}_{37} \mathrm{H}_{68} \mathrm{O}_{8} \mathrm{PKK}^{+}$ & 749.3926 & 0.0020 & 2.7 \\
\hline 751.4139 & 512 & 0.0017 & $(\mathrm{PL}) \mathrm{C}_{37} \mathrm{H}_{70} \mathrm{O}_{8} \mathrm{PKK}^{+}$ & 751.4082 & 0.0057 & 7.6 \\
\hline 752.5242 & 2048 & 0.0021 & {$[\mathrm{PC} 32: 2+\mathrm{Na}]^{+}$} & 752.5206 & 0.0036 & 4.8 \\
\hline 754.4831 & 2048 & 0.0021 & {$[\mathrm{PE} 34: 2+\mathrm{K}]^{+}$} & 754.4789 & 0.0042 & 5.6 \\
\hline 754.5425 & 2048 & 0.0026 & {$[\mathrm{PC} 32: 1+\mathrm{Na}]^{+}$} & 754.5363 & 0.0062 & 8.2 \\
\hline 758.5713 & 2048 & 0.0025 & {$[\mathrm{PC} 34: 2+\mathrm{H}]^{+}$} & 758.5700 & 0.0013 & 1.7 \\
\hline 760.5887 & 512 & 0.0018 & {$[\mathrm{PC} 34: 1+\mathrm{H}]^{+}$} & 760.5856 & 0.0031 & 4.1 \\
\hline 764.4041 & 2048 & 0.0038 & {$\left[\mathrm{PE} 32: 2+\mathrm{K}_{2}-\mathrm{H}\right]^{+}$} & 764.4034 & 0.0007 & 0 \\
\hline 765.4850 & 512 & 0.0033 & $(\mathrm{PL}) \mathrm{C}_{41} \mathrm{H}_{75} \mathrm{O}_{8} \mathrm{PK}^{+}$ & 765.4837 & 0.0013 & 1.7 \\
\hline 766.4269 & 2048 & 0.0010 & {$\left[\mathrm{PE} 32: 1+\mathrm{K}_{2}-\mathrm{H}\right]^{+}$} & 766.4191 & 0.0078 & 10.2 \\
\hline 766.4906 & 2048 & 0.0017 & {$[\mathrm{PC} 32: 3+\mathrm{K}]^{+}$} & 766.4789 & 0.0117 & 15.3 \\
\hline 768.4984 & 2048 & 0.0017 & {$[\mathrm{PC} 32: 2+\mathrm{K}]^{+}$} & 768.4946 & 0.0038 & 4.9 \\
\hline 770.5132 & 2048 & 0.0018 & {$[\mathrm{PC} 32: 1+\mathrm{K}]^{+}$} & 770.5102 & 0.0030 & 3.9 \\
\hline 772.5168 & 512 & 0.0018 & {$[\mathrm{PC} 32: 0+\mathrm{K}]^{+}$} & 772.5259 & -0.0091 & -11.8 \\
\hline 772.5854 & 512 & 0.0028 & {$[\mathrm{PE} 38: 2+\mathrm{H}]^{+}$} & 772.5856 & -0.0002 & -0.3 \\
\hline 780.5525 & 2048 & 0.0024 & {$[\mathrm{PC} 34: 2+\mathrm{Na}]^{+}$} & 780.5519 & 0.0006 & 0.8 \\
\hline 782.5703 & 1024 & 0.0024 & {$[\mathrm{PC} 34: 1+\mathrm{Na}]^{+}$} & 782.5676 & 0.0027 & 3.5 \\
\hline 792.4392 & 2048 & 0.0028 & {$\left[\mathrm{PE} 34: 2+\mathrm{K}_{2}-\mathrm{H}\right]^{+}$} & 792.4348 & 0.0044 & 5 \\
\hline 794.4481 & 2048 & 0.0081 & {$\left[\mathrm{PE} 34: 1+\mathrm{K}_{2}-\mathrm{H}\right]^{+}$} & 794.4504 & 0.0023 & 2.9 \\
\hline 796.5265 & 2048 & 0.0061 & {$[\mathrm{PC} 34: 2+\mathrm{K}]^{+}$} & 796.5259 & 0.0006 & 0.8 \\
\hline 798.5412 & 2048 & 0.0013 & {$[\mathrm{PC} 34: 1+\mathrm{K}]^{+}$} & 798.5415 & -0.0003 & -0.4 \\
\hline 820.4718 & 2048 & 0.0031 & {$\left[\mathrm{PE} 36: 2+\mathrm{K}_{2}-\mathrm{H}\right]^{+}$} & 820.4661 & 0.0057 & 6.9 \\
\hline 824.5595 & 1024 & 0.0016 & {$[\mathrm{PC} 36: 2+\mathrm{K}]^{+}$} & 824.5572 & 0.0023 & 2.8 \\
\hline 826.5744 & 1024 & 0.0038 & {$[\mathrm{PC} 36: 1+\mathrm{K}]^{+}$} & 826.5728 & 0.0016 & 1.9 \\
\hline 875.5090 & 1024 & 0.0015 & {$[\mathrm{PI} 34: 1+\mathrm{K}]^{+}$} & 875.5052 & 0.0038 & 4.3 \\
\hline 885.4359 & 1024 & 0.0012 & {$\left[\mathrm{PI} 32: 1+\mathrm{K}_{2}-\mathrm{H}\right]^{+}$} & 885.4298 & 0.0061 & 6.9 \\
\hline 913.4686 & 1024 & 0.0011 & {$\left[\mathrm{PI} 34: 1+\mathrm{K}_{2}-\mathrm{H}\right]^{+}$} & 913.4611 & 0.0075 & 8.2 \\
\hline Average & & 0.0020 & & & 0.0032 & 4.3 \\
\hline
\end{tabular}


Table 4. Observed fragmentation for ions originating form PC. It should be noted that parent ions shifted +1 Da in ${ }^{15} \mathrm{~N}$ media while ions resulting from fragmentation did not shift.

\begin{tabular}{|c|c|c|c|c|c|c|}
\hline Parent ion & Assignment & $\begin{array}{l}\text { Elemental } \\
\text { composition }\end{array}$ & $\begin{array}{l}\text { Fragment } \\
\text { ion }\end{array}$ & TriMethyl amine loss & $\begin{array}{c}\text { Isomeric } \\
\text { assignment }\end{array}$ & $\begin{array}{l}\text { Elemental } \\
\text { composition }\end{array}$ \\
\hline 826. & C 36:1+ & $\mathrm{O}_{8}$ NPK & & & & \\
\hline 824. & {$[\mathrm{PC} 36: 2+\mathrm{K}]^{+}$} & $\mathrm{C}_{44} \mathrm{H}_{84} \mathrm{O}_{8} \mathrm{NPK}$ & 765.4860 & {$\left[\mathrm{PC}-\mathrm{N}\left(\mathrm{CH}_{3}\right)_{3} 36: 2+\mathrm{K}\right]^{+}$} & {$[\mathrm{PA} 38: 3+\mathrm{K}]^{+}$} & $\mathrm{C}_{41} \mathrm{H}_{75} \mathrm{O}_{8} \mathrm{PK}$ \\
\hline 798.5 & {$[\mathrm{PC} 34: 1+\mathrm{K}]^{+}$} & $\mathrm{C}_{42} \mathrm{H}_{82} \mathrm{O}_{8} \mathrm{NPK}$ & & {$\left[\mathrm{PC}-\mathrm{N}\left(\mathrm{CH}_{3}\right)_{3} 34: 1+\mathrm{K}\right]^{+}$} & {$[\mathrm{PA} 36: 2+\mathrm{K}]^{+}$} & $\mathrm{C}_{39} \mathrm{H}_{73} \mathrm{O}_{8} \mathrm{PK}$ \\
\hline 796 & {$[\mathrm{PC} 34: 2+\mathrm{K}]^{+}$} & $\mathrm{C}_{42} \mathrm{H}_{80} \mathrm{O}_{8} \mathrm{NPK}$ & 737.4530 & {$\left[\mathrm{PC}-\mathrm{N}\left(\mathrm{CH}_{3}\right)_{3} 34: 2+\mathrm{K}\right]^{+}$} & {$[\mathrm{PA} 36: 3+\mathrm{K}]^{+}$} & $\mathrm{C}_{39} \mathrm{H}_{71} \mathrm{O}_{8} \mathrm{PK}$ \\
\hline 782 & 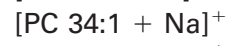 & $\mathrm{C}_{42} \mathrm{H}_{82} \mathrm{O}_{8} \mathrm{NPNa}$ & & & & \\
\hline 780. & {$[\mathrm{PC} 34: 2+\mathrm{Na}]^{+}$} & $\mathrm{C}_{42} \mathrm{H}_{80} \mathrm{O}_{8} \mathrm{NPNa}$ & 721.4790 & {$\left[\mathrm{PC}-\mathrm{N}\left(\mathrm{CH}_{3}\right)_{3} 34: 2+\mathrm{Na}\right]^{+}$} & {$[\mathrm{PA} 36: 3+\mathrm{Na}]^{+}$} & $\mathrm{C}_{39} \mathrm{H}_{71} \mathrm{O}_{8} \mathrm{PNa}$ \\
\hline 772. & {$[\mathrm{PC} 32: 0+\mathrm{K}]^{+}$} & $\mathrm{C}_{40} \mathrm{H}_{80} \mathrm{O}_{8} \mathrm{NPK}$ & 713.4433 & {$\left[\mathrm{PC}-\mathrm{N}\left(\mathrm{CH}_{3}\right)_{3} 32: 0+\mathrm{K}\right]^{+}$} & {$[\mathrm{PA} 34: 1+\mathrm{K}]^{+}$} & $\mathrm{C}_{37} \mathrm{H}_{71} \mathrm{O}_{8} \mathrm{PK}$ \\
\hline 770.5132 & {$[\mathrm{PC} 32: 1+\mathrm{K}]^{+}$} & $\mathrm{C}_{40} \mathrm{H}_{78} \mathrm{O}_{8} \mathrm{NPK}$ & 711.4397 & {$\left[\mathrm{PC}-\mathrm{N}\left(\mathrm{CH}_{3}\right)_{3} 32: 1+\mathrm{K}\right]^{+}$} & {$[\mathrm{PA} 34: 2+\mathrm{K}]^{+}$} & $\mathrm{C}_{37} \mathrm{H}_{69} \mathrm{O}_{8} \mathrm{PK}$ \\
\hline 768.4984 & {$[\mathrm{PC} 32: 2+\mathrm{K}]^{+}$} & $\mathrm{C}_{40} \mathrm{H}_{76} \mathrm{O}_{8} \mathrm{NPK}$ & 709.4249 & {$\left[\mathrm{PC}-\mathrm{N}\left(\mathrm{CH}_{3}\right)_{3} 32: 2+\mathrm{K}\right]^{+}$} & {$[\mathrm{PA} 34: 3+\mathrm{K}]^{+}$} & $\mathrm{C}_{37} \mathrm{H}_{67} \mathrm{O}_{8} \mathrm{PK}$ \\
\hline 754.5425 & 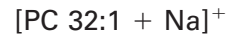 & $\mathrm{C}_{40} \mathrm{H}_{78} \mathrm{O}_{8} \mathrm{NPNa}$ & 695.4690 & {$\left[\mathrm{PC}-\mathrm{N}\left(\mathrm{CH}_{3}\right)_{3} 32: 1+\mathrm{Na}\right]^{+}$} & {$[\mathrm{PA} 34: 2+\mathrm{Na}]^{+}$} & ${ }_{69} \mathrm{O}_{8} \mathrm{PNa}$ \\
\hline 752.5242 & {$[\mathrm{PC} 32: 2+\mathrm{Na}]^{+}$} & $\mathrm{C}_{40} \mathrm{H}_{76} \mathrm{O}_{8} \mathrm{NPNa}$ & 693.4507 & {$\left[\mathrm{PC}-\mathrm{N}\left(\mathrm{CH}_{3}\right)_{3} 32: 2+\mathrm{Na}\right]^{+}$} & {$[\mathrm{PA} 34: 3+\mathrm{Na}]^{+}$} & $\mathrm{C}_{37} \mathrm{H}_{67} \mathrm{O}_{8} \mathrm{PNa}$ \\
\hline 742.4798 & {$[\mathrm{PC} 30: 1+\mathrm{K}]^{+}$} & $\mathrm{C}_{38} \mathrm{H}_{74} \mathrm{O}_{8} \mathrm{NPK}$ & 683.4063 & {$\left[\mathrm{PC}-\mathrm{N}\left(\mathrm{CH}_{3}\right)_{3} 30: 1+\mathrm{K}\right]^{+}$} & {$[\mathrm{PA} 32: 2+\mathrm{K}]^{+}$} & $\mathrm{C}_{35} \mathrm{H}_{65} \mathrm{O}_{8} \mathrm{PK}$ \\
\hline 714.4506 & {$[\mathrm{PC} 28: 1+\mathrm{K}]^{+}$} & $\mathrm{C}_{36} \mathrm{H}_{70} \mathrm{O}_{8} \mathrm{NPK}$ & 655.3771 & {$\left[\mathrm{PC}-\mathrm{N}\left(\mathrm{CH}_{3}\right)_{3} 28: 1+\mathrm{K}\right]^{+}$} & {$[\mathrm{PA} 30: 2+\mathrm{K}]^{+}$} & $\mathrm{C}_{33} \mathrm{H}_{61} \mathrm{O}_{8} \mathrm{PK}$ \\
\hline
\end{tabular}

\section{References}

1. Stump, M. J.; Fleming, R. C.; Gong, W.; Jaber, A. J.; Jones, J. J.; Surber, C. W.; Wilkins, C. L. Matrix-Assisted Laser Desorption Mass Spectrometry. Appl. Spectrosc. Rev. 2002, 37, 275-303.

2. Lay, J. O. MALDI-TOF Mass Spectrometry of Bacteria. Mass Spectrom. Rev. 2001, 20, 172-194.

3. Fenselau, C.; Demirev, P. A. Characterization of Intact Microorganisms by MALDI Mass Spectrometry. Mass Spectrom. Rev. 2001, 20, 157-171.

4. van Baar, B. L. M. Characterization of Bacteria by MatrixAssisted Laser Desorption/IoniZation and Electrospray Mass Spectrometry. FEMS Microbiol. Rev. 2000, 24, 193-219.

5. Lay, J. O.; Holland, R. D. In Mass Spectrometry of Proteins and Peptides; Chapman, J. R., Ed.; Humana Press: Totowa, NJ, 2000, pp 461-488.

6. Jones, J. J.; Stump, M. J.; Fleming, R. C.; Lay, J. O.; Wilkins, C. L. Investigation of MALDI-TOF and FT-MS Techniques for Analysis of Escherichia coli Whole Cells. Anal. Chem. 2003, 75, $1340-1347$.

7. Stump, M. J.; Jones, J. J.; Fleming, R. C.; Lay, J. O.; Wilkins, C. L. Use of Double-Depleted ${ }^{13} \mathrm{C}$ and ${ }^{15} \mathrm{~N}$ Culture Media for Analysis of Whole Cell Bacteria by MALDI Time-of-Flight and Fourier Transform Mass Spectrometry. J. Am. Soc. Mass Spectrom. 2003, 14, 1306-1314.

8. Ingram, J. C.; Bauer, W. F.; Lehman, R. M.; O'Connell, S. P.; Shaw, A. D. Detection of Fatty Acids from Intact Microorganisms by Molecular Beam Static Secondary Ion Mass Spectrometry. J. Microbiol. Methods 2003, 53, 295-307.

9. Ho, Y. P.; Fenselau, C. Applications of $1.06 \mu \mathrm{m}$ IR Laser Desorption on a Fourier Transform Mass Spectrometer. Anal. Chem. 1998, 70, 4890-4895.

10. Lechevalier, M. P. Lipids in Bacterial Taxonomy-A Taxonomist's View. Crit. Rev. Microbiol. 1977, 5, 109-210.

11. Marto, J. A.; White, F. M.; Seldomridge, S.; Marshall, A. G. Structural Characterization of Phospholipids by Matrix-Assisted Laser Desorption/Ionization Fourier Transform Ion Cyclotron Resonance Mass Spectrometry. Anal. Chem. 1995, 67, 3979-3984.

12. Lee, S. H.; Williams, M. V.; DuBois, R. N.; Blair, I. A. Targeted Lipidomics Using Electron Capture Atmospheric Pressure Chemical Ionization Mass Spectrometry. Rapid Commun. Mass Spectrom. 2003, 17, 2168-2176.

13. Kishimoto, K.; Urade, R.; Ogawa, T.; Moriyama, T. Nondestructive Quantification of Neutral Lipids by Thin-Layer Chromatography and Laser-Fluorescent Scanning: Suitable Methods for "Lipidome" Analysis. Biochem. Biophys. Res. Commun. 2001, 281, 657-662.
14. Sasser, M. In Methods in Phytobacteriology; Klement, Z.; Rudolph, K.; Sands, D. C., Eds.; Akademiai Kiado: Budapest, 1990; pp 199-204.

15. Wauthoz, P.; Lioui, M.; Decallonne, J. Gas Chromatography of Cellular Fatty Acids in the Identification of Food-Borne Bacteria. J. Food Product. 1995, 58, 1234-1240.

16. Basile, F.; Voorhees, K. J.; Hadfield, T. L. Microorganism Gram-Type Differentiation Based on Pyrolysis Mass Spectrometry of Bacterial Fatty Acid Methyl Ester Extracts. Appl. Environ. Microbiol. 1995, 61, 1534-1539.

17. DeLuca, S.; Sarver, E. W.; Harrungton, P. B.; Voorhees, K. J. Direct Analysis of Bacterial Fatty Acids by Curie-Point Pyrolysis Tandem Mass Spectrometry. Anal. Chem. 1990, 62, 14651472.

18. Griffiths, W. J. Tandem Mass Spectrometry in the Study of Fatty Acids, Bile Acids, and Steroids. Mass Spectrom. Rev. 2003, $22,81-152$.

19. Heller, D. N.; Murphy, C. M.; Cotter, R. J.; Fenselau, C.; Uy, O. M. Constant Neutral Loss Scanning for the Characterization of Bacterial Phospholipids Desorbed by Fast Atom Bombardment. Anal. Chem. 1988, 60, 1787-1791.

20. Cole, M. J.; Enke, C. G. Direct Determination of Phospholipid Structures in Microorganisms by Fast Atom Bombardment Triple Quadrupole Mass Spectrometry. Anal. Chem. 1991, 63, 1032-1038.

21. Heller, D. N.; Cotter, R. J.; Fenselau, C.; Uy, O. M. Profiling of Bacteria by Fast Atom Bombardment Mass Spectrometry. Anal. Chem. 1987, 59, 2806-2809.

22. Gurtler, V.; Mayall, B. C. Genomic Approaches to Typing, Taxonomy, and Evolution of Bacterial Isolates. Int. J. Sys. Evol. Microbiol. 2001, 51, 3-16.

23. Tyers, M.; Mann, M. From Genomics to Proteomics. Nature 2003, 422, 193-197.

24. Phizicky, E.; Bastiaens, P. I. H.; Zhu, H.; Snyder, M.; Fields, S. Protein Analysis on a Proteomic Scale Nature 2003, 422, 208-215.

25. Shevchenko, A.; Sunyaev, S.; Loboda, A.; Shevchenko, A.; Bork, P.; Ens, W.; Standing, K. G. Charting the Proteomes of Organisms with Unsequenced Genomes by MALDI-Quadrupole Time-of-Flight Mass Spectrometry and BLAST Homology Searching. Anal. Chem. 2001, 73, 1917-1926.

26. Ryzhov, V.; Fenselau, C. Characterization of the Protein Subset Desorbed by MALDI from Whole Bacterial Cells. Anal. Chem. 2001, 73, 746-750.

27. Smole, S. C.; King, L. A.; Leopold, P. E.; Arbeit, R. D. Sample Preparation of Gram-Positive Bacteria for Identification by 
Matrix Assisted Laser Desorption/Ionization Time-of-Flight. J. Microbiol. Methods 2002, 48, 107-115.

28. Conway, G. C.; Smole, S. C.; Sarracino, D. A.; Arbeit, R. D.; Leopold, P. E. Phyloproteomics: Species Identification of Enterobacteriaceae Using Matrix-Assisted Laser Desorption/Ionization Time-of-Flight Mass Spectrometry. J. Mol. Microbiol. Biotechnol. 2001, 3, 103-112.

29. Ishida, Y.; Madonna, A. J.; Rees, J. C.; Meetani, M. A.; Voorhees, K. J. Rapid Analysis of Intact Phospholipids from Whole Bacterial Cells by Matrix-Assisted Laser Desorption/ Ionization Mass Spectrometry Combined with On-Probe Sample Pretreatment. Rapid Commun. Mass Spectrom. 2002, 16, 1877-1882.

30. Schiller, J.; Arnhold, J.; Benard, S.; Muller, M.; Reichl, S.; Arnold, K. Lipid Analysis by Matrix-Assisted Laser Desorption and Ionization Mass Spectrometry: A Methodological Approach. Anal. Biochem. 1999, 267, 46-56.

31. Christie, W. W. Lipid Analysis, 1st ed.; Pergamon Press Ltd.: New York, 1973.

32. Al-Saad, K. A.; Zabrouskov. V.; Siems, W. F.; Knowles, N. R.; Hannan, R. M.; Hill, H. H. Matrix Assisted Laser Desorption/ Ionization Time-of-Flight Mass Spectrometry of Lipids Ionization and Prompt Fragmentation Patterns. Rapid Commun. Mass Spectrom. 2003, 17, 87-96.

33. Zabrouskov, V.; Al-Saad, K. A.; Siems, W. F.; Hill, H. H.; Knowles, N. R. Analysis of Plant Phosphotydalcholines by Matrix-Assisted Laser Desorption/Ionization Time-of-Flight Mass Spectrometry. Rapid Commun. Mass Spectrom. 2001, 15, 935-940.

34. Cvacka, J.; Svatos, A. Matrix-Assisted Laser Dosorption/ Ionization Analysis of Lipids and High Molecular Weight Hydrocarbons with Lithium 2,5-dihydroxybenzoate Matrix. Rapid Commun. Mass Spectrom. 2003, 17, 2203-2207.

35. Zubarev, R. A.; Hakansson, P.; Sundqvist, B. Accuracy Requirements for Peptide Characterization by Monoisotopic Molecular Mass Measurements. Anal. Chem. 1996, 68, 40604063.
36. Ledford, E. B., Jr.; Rempel, D. L.; Gross, M. L. Space Charge Effects in Fourier Transform Mass Spectrometry. Mass Calibration. Anal. Chem. 1984, 56, 2744-2748.

37. Hughey, C. A.; Hendrickson, C. L.; Rodgers, R. P.; Marshall, A. G. Kendrick Mass Defect Spectrum: A Compact Visual Analysis for Ultrahigh-Resolution Broadband Mass Spectra. Anal. Chem. 2001, 73, 4676-4681.

38. Kendrick, E. A Mass Scale Based on $\mathrm{CH}=14.0000$ for High Resolution Mass Spectrometry of Organic Compounds. Anal. Chem. 1963, 35, 2146-2154.

39. Kim, S.; Kramer, R. W.; Hatcher, P. G. Graphical Method for Analysis of Ultrahigh-Resolution Broadband Mass Spectra of Natural Organic Matter, the Van Krevelen Diagram. Anal. Chem. 2003, 75, 5336-5344.

40. $\mathrm{Wu}$, Z., Rodgers,, R. P., Marshall,, A. G. Two- and ThreeDimensional van Krevelen Diagrams: A Graphical Analysis Complementary to the Kendrick Mass Plot for Sorting Elemental Compositions of Complex Organic Mixtures Based on Ultrahigh-Resolution Broadband Fourier Transform Ion Cyclotron Resonance Mass Measurements. Anal. Chem., in press.

41. Schneiter, R.; Brugger, B.; Sandhoff, R.; Zellnig, G.; Leber, A.; Lampl, M.; Athenstaedt, K.; Hrastnik, C.; Eder, S.; Daum, G.; Paltauf, F.; Wieland, F. T.; Kohlwein, S. D. Electrospray Ionization Tandem Mass Spectrometry (ESI-MS/MS) Analysis of the Lipid Molecular Species Composition of Yeast Subcellular Membranes Reveals Acyl Chain-Based Sorting/Remodeling of Distinct Molecular Species en Route to the Plasma Membrane. J. Cell Biol. 1999, 146, 741-754.

42. Jones, J. J.; Stump, M. J.; Lay, J. O.; Wilkins, C. L. Mass Sefect Plots of High Resolution MALDI FTMD Whole Cell Bacterial Data Used as an Aid in Rapid Lipid Characterization, Proceedings of the 50th ASMS Conference on Mass Spectrometry and Allied Topics, Orlando, FL, June 2002.

43. Kaufman, J. M.; Jaber, A. J.; Stump, M. J.; Simonsick, W. J.; Wilkins, C. L. Interference from Multiple Cations in MALDI-MS Spectra of Copolymers. Int. J. Mass Spectrom. 2004, $234,153-160$. 